\title{
Herbicides for Highway Rights-of-Way 1
}

J.A. Ferrell and K. A. Langeland ${ }^{2}$

\begin{tabular}{|c|c|c|}
\hline \multicolumn{2}{|c|}{ Postemergence Broadcast Applications } & \\
\hline Herbicide & Rate & Comments \\
\hline $\begin{array}{l}\text { Arsenal or Arsenal } \\
\text { Powerline } \\
\text { BASF Corp }\end{array}$ & $\begin{array}{l}64 \text { floz/A } \\
\text { Surfactant required: } \\
0.5 \% \mathrm{v} / \mathrm{v} \text { NIS } \\
\text { or } \\
1 \% \mathrm{v} / \mathrm{v} \text { MSO }\end{array}$ & $\begin{array}{l}\text { For control of cogongrass and undesirable trees only. DO NOT apply } \\
\text { Arsenal to turf or complete death will occur. DO NOT apply Arsenal } \\
\text { over the root-zone of desirable trees. Arsenal possesses considerable } \\
\text { soil residual activity and application can result in bare ground for several } \\
\text { weeks or months. For best results, spray cogongrass when actively } \\
\text { growing in the fall. }\end{array}$ \\
\hline $\begin{array}{l}\text { 2,4-D amine } \\
\text { (Hi-Dep, others) }\end{array}$ & 2 to $4 \mathrm{pt} / \mathrm{A}$ & $\begin{array}{l}\text { Excellent postemergence control of broadleaf weeds including Spanish } \\
\text { needle, pigweed, Carolina geranium, and wild radish. Possesses little or } \\
\text { no soil residual activity against most weeds. The use rate of } 2 \text { pt/A will } \\
\text { be highly effective on most broadleaf weeds that are less than } 4 \text { inches } \\
\text { in height. 2,4-D is weak on briars and almost all "brush" weeds. } \\
\text { The Organo-auxin rule must be obeyed when using this herbicide. } \\
\text { The amine formulation is essentially non-volatile, but application of the } \\
\text { ester formulation is not advised. Applications near sensitive crops } \\
\text { (vegetables, cotton, tobacco) should be avoided. }\end{array}$ \\
\hline Garlon 3A & $\begin{array}{l}1 \text { to } 2 \mathrm{pt} / \mathrm{A} \\
6-8 \mathrm{qt} / \mathrm{A} \text {, brush }\end{array}$ & $\begin{array}{l}\text { Effective for various broadleaf weeds and hard to manage species such } \\
\text { as briars and brush. } \\
\text { The Organo-auxin rule must be obeyed when using this herbicide. } \\
\text { An essentially non-volatile triclopyr amine formulation, but application } \\
\text { near sensitive crops (vegetables, cotton, tobacco) when physical drift } \\
\text { could occur should be avoided. }\end{array}$ \\
\hline Garlon 4 Ultra & $\begin{array}{l}\text { 8-16 fl oz/A } \\
4-6 \mathrm{qt} / \mathrm{A}, \text { brush }\end{array}$ & $\begin{array}{l}\text { Control spectrum is similar to Garlon } 3 \mathrm{~A} \text {, but the } 4 \mathrm{EC} \text { formulation is } \\
\text { generally more potent. } \\
\text { The Organo-auxin rule must be obeyed when using this herbicide. } \\
\text { A somewhat volatile triclopyr ester formulation. Application near } \\
\text { sensitive crops (vegetables, cotton, tobacco) should be avoided. }\end{array}$ \\
\hline
\end{tabular}

1. This document is SS-AGR-271, one of a series of the Agronomy Department, Florida Cooperative Extension Service, Institute of Food and Agricultural Sciences, University of Florida. Original publication date July 2007. Visit the EDIS Web Site at http://edis.ifas.ufl.edu.

2. J. A. Ferrell, assistant professor, Department of Agronomy; K.A. Langeland, Professor, Agronomy Department, Center for Aquatic and Invasive Plants, Cooperative Extension Service, Institute of Food and Agricultural Sciences, University of Florida, Gainesville, FL 32611.

The use of trade names in this publication is solely for the purpose of providing specific information. UF/IFAS does not guarantee or warranty the products named, and references to them in this publication does not signify our approval to the exclusion of other products of suitable composition. All chemicals should be used in accordance with directions on the manufacturer's label.

The Institute of Food and Agricultural Sciences (IFAS) is an Equal Opportunity Institution authorized to provide research, educational information and other services only to individuals and institutions that function with non-discrimination with respect to race, creed, color, religion, age, disability, sex, sexual orientation, marital status, national origin, political opinions or affiliations. U.S. Department of Agriculture, Cooperative Extension Service, University of Florida, IFAS, Florida A. \& M. University Cooperative Extension Program, and Boards of County Commissioners Cooperating. Larry Arrington, Dean 


\begin{tabular}{|c|c|c|}
\hline \multicolumn{2}{|c|}{ Postemergence Broadcast Applications } & \multirow[b]{2}{*}{ Comments } \\
\hline Herbicide & Rate & \\
\hline Vanquish & 4 to 32 fl. oz/A & $\begin{array}{l}\text { Vanquish is similar in activity and complimentary to } 2,4-\mathrm{D} \text {. Short-lived } \\
\text { residual activity is often observed on certain weed species. } \\
\text { The Organo-auxin rule must be obeyed when using this herbicide. } \\
\text { Vanquish is volatile and any application near sensitive crops } \\
\text { (vegetables, cotton, tobacco) should be avoided. }\end{array}$ \\
\hline Vista* $^{*}$ & 8-16 fl oz/A & $\begin{array}{l}\text { Effective for various broadleaf weeds; very effective on dogfennel. } \\
\text { The Organo-auxin rule must be obeyed when using this herbicide. } \\
\text { An essentially non-volatile fluroxypyr ester formulation, but application } \\
\text { near sensitive crops (vegetables, cotton, tobacco) when physical drift } \\
\text { could occur should be avoided. Safe to use in the root zone of desirable } \\
\text { trees. }\end{array}$ \\
\hline Overdrive* & 4 to 8 oz/A dry weight & For post emergent broadleaf weed control with little soil activity. \\
\hline \multicolumn{3}{|c|}{$\begin{array}{l}\text { Postemergence Broadcast applications - } \\
\text { Dormant grass }\end{array}$} \\
\hline Herbicide & Rate & Comments \\
\hline $\begin{array}{l}\text { Glyphosate } \\
\text { (Roundup Pro, Accord } \\
\mathrm{XRT}^{\star} \text {, etc) }\end{array}$ & 0.5 to $4 \mathrm{pt} / \mathrm{A}$ & $\begin{array}{l}\text { For use where total vegetation control is desired. If broadcast, desirable } \\
\text { turf must be dormant or excessive injury or death will occur. DO NOT } \\
\text { apply glyphosate where wildflowers are present. } \\
\text { Glyphosate provides excellent control of most broadleaf and grass } \\
\text { weeds, but possesses no soil residual activity. Glyphosate works well } \\
\text { when mixed with 2,4-D, Milestone VM, or other herbicides. }\end{array}$ \\
\hline
\end{tabular}




\begin{tabular}{|c|c|c|}
\hline \multicolumn{2}{|c|}{$\begin{array}{l}\text { Postemergence Broadcast Applications - } \\
\text { Guard Rails or other locations where total } \\
\text { vegetation control is desired }\end{array}$} & \\
\hline Herbicide & Rate & Comments \\
\hline $\begin{array}{l}\text { Glyphosate } \\
\text { (Roundup Pro, Accord } \\
\mathrm{XRT}^{\star} \text {, etc) }\end{array}$ & $\begin{array}{l}0.5 \text { to } 4 \mathrm{pt} / \mathrm{A} \\
\text { or } \\
1 \text { to } 3 \% \text { solution }\end{array}$ & $\begin{array}{l}\text { Glyphosate has no soil residual activity. Expect weeds to die within } 14 \\
\text { days of application, but to recolonize from seed within } 1 \text { to } 2 \text { months } \\
\text { after application. Weeds must be actively growing for glyphosate to be } \\
\text { effective. Low rates are effective on air potato when applied in late } \\
\text { summer/early fall. Many species (such as oaks) are fairly tolerant of low } \\
\text { rates. }\end{array}$ \\
\hline Journey* BASF Corp & $\begin{array}{l}32 \mathrm{fl} \mathrm{oz} / \mathrm{A} \\
\text { Surfactant required: } \\
0.5 \% \mathrm{v} / \mathrm{v} \mathrm{NIS} \\
\text { or } \\
1 \% \mathrm{v} / \mathrm{v} \mathrm{MSO}\end{array}$ & $\begin{array}{l}\text { Excellent control of most grass and broadleaf weeds. Significant soil } \\
\text { residual activity for weeks or months after application. May be mixed } \\
\text { with glyphosate } 1 \mathrm{qt} \mathrm{fl} \text { oz/A for additional knock down of larger vegetation. }\end{array}$ \\
\hline Milestone VM & $\begin{array}{l}7 \mathrm{fl} \mathrm{oz} / \mathrm{A} ; 14 \mathrm{fl} \mathrm{oz} / \mathrm{A} \text {, } \\
\text { spot applications }\end{array}$ & $\begin{array}{l}\text { Excellent postemergence control of broadleaf weeds including Spanish } \\
\text { needle, pigweed, ragweed, Carolina geranium, tropical soda apple, } \\
\text { thistle, Florida betony and marestail. Possesses several months of soil } \\
\text { residual activity on tropical soda apple, ragweed, Spanish needle, and } \\
\text { marestail. Milestone VM is weak on dogfennel. Should be mixed with } \\
\text { glyphosate for grass control. } \\
\text { The Organo-auxin rule must be obeyed when using this herbicide. } \\
\text { An essentially non-volatile aminopyralid amine formulation, but } \\
\text { application near sensitive crops (vegetables, cotton, tobacco) when } \\
\text { physical drift could occur should be avoided. }\end{array}$ \\
\hline
\end{tabular}

